\title{
Chemical Kinetic Characteristics of Phosphorus Migration in Aqueous Background of Wetland
}

\author{
Hong Yan Li ${ }^{1,2}$, Guang Xin Zhang ${ }^{3 *}$, Jin Hua Gao ${ }^{1,4}$ \\ ${ }^{1}$ School of Water Conservancy and Environmental Engineering, Changchun Institute of Technology, \\ Changchun 130012, China \\ ${ }_{2}^{2}$ Jilin Provincial Key Laboratory of Municipal Wastewater Treatment, Changchun 130012, China \\ ${ }^{3}$ Key Laboratory of Wetland Ecology and Environment, Northeast Institute of Geography and Agroecology, \\ Chinese Academy of Sciences, Changchun 130102 \\ ${ }^{4}$ Laboratory of Applied Disaster Prevention in Water Conservation Engineering of Jilin Province, \\ Changchun 130012, China
}

Received: 21 July 2016

Accepted: 3 November 2016

\begin{abstract}
For this paper we simulated wastewater containing organic phosphorus degradation process across the wetland via organic phosphorus containing solutions of different $\mathrm{pH}$ values slowly passing the simulation groove so as to explore the chemical kinetic characteristics of phosphorus migration in the aqueous backgrounds of different wetlands. Our study shows that the migration performance of organic phosphorus in the wetland declines while $\mathrm{pH}$ value increases, and that the mineralization of organic phosphorus in clay pan increases with enhanced $\mathrm{pH}$ value. The mineralization rate of organic phosphorus in the eighth day may reach over $74 \%(\mathrm{pH} \geq 7)$ or above $90 \%$ when $\mathrm{pH}=9.0$. The concentration of $\mathrm{PO}_{4}^{3-}$, which is the direct product of mineralization of organic phosphorus, decreases somewhat when the $\mathrm{pH}$ value increases or as time passes. Our study provides the parameter basis to explore the purification mechanism and determine the chemical kinetic mode of organic phosphorus migration in aqueous background of the wetland.
\end{abstract}

Keywords: phosphorus, $\mathrm{pH}$, dynamics, migration, wetland

\section{Introduction}

Functioning as a link between land and water bodies, wetlands purify polluted waters by removing nitrogen and phosphorus through a series of physicochemical processes [1-5]. However, such purification capacity is limited. If the optimal function of the wetland is to be maintained, precaution must be taken to prevent pollution and deterioration of wetland water quality [6-8]. Excessive

*e-mail: zhgx@ neigae.ac.cn amounts of nutrients, such as nitrogen and phosphorus, often overflow into natural wetlands, exerting a pollution load that seriously threatens wetland ecosystems. In recent years, non-point water pollution due to agricultural activities is causing increasing environmental and social concerns. Zhalong Nature Reserve has been included in the Directory of Important Wetlands in the World. Currently, large-scale inflows of waters with rich nutrient contents (such as nitrogen and phosphorus), pose the most serious threat to the wetland reserve and its ecosystem [9-12]. Therefore, it is an important issue to study the pollution procedure and degree caused by the migration 
of organic phosphorus in the wetland environment. As the wetland environment of different $\mathrm{pH}$ values produces different influence on the migration and conversion of organic phosphorus, the degradation process of wastewater containing organic phosphorus across the wetland is stipulated in this paper via organic phosphorus containing solutions of different $\mathrm{pH}$ values passing slowly by the wetland. Our study was conducted on the chemical kinetic characteristics of phosphorus migration in aqueous background in wetlands so as to explore the chemical kinetic characteristics of phosphorus migration in the aqueous background of different wetlands.

\section{Material and Methods}

\section{Study Area and Experimental Apparatus}

Zhalong Wetland is located in western Songnen Plain, along the lower Wuyuer River and Shuang Yang River basin (Fig. 1), a typical riverside wetland with a total area of 2,100 $\mathrm{km}^{2}$. Reed marsh, which is the largest and most widely distributed landscape feature in the Wuyuer River basin, is an important feature of Zhalong Wetland. A typical swamp wetland was chosen as the prototype of simulation (Fig. 1), based on outdoor investigations and tests. This area was the main load-bearing area of drainage with geographical coordinates of $124^{\circ} 11^{\prime} 38^{\prime \prime}-124^{\circ} 14^{\prime} 14^{\prime \prime}$ east longitude and $47^{\circ} 10^{\prime} 19^{\prime \prime}-47^{\circ} 13^{\prime} 16^{\prime \prime}$ north latitude. Alongside water and reeds, soil samples (with depth reaching $45 \mathrm{~cm}$ ) were collected from the wetland, which

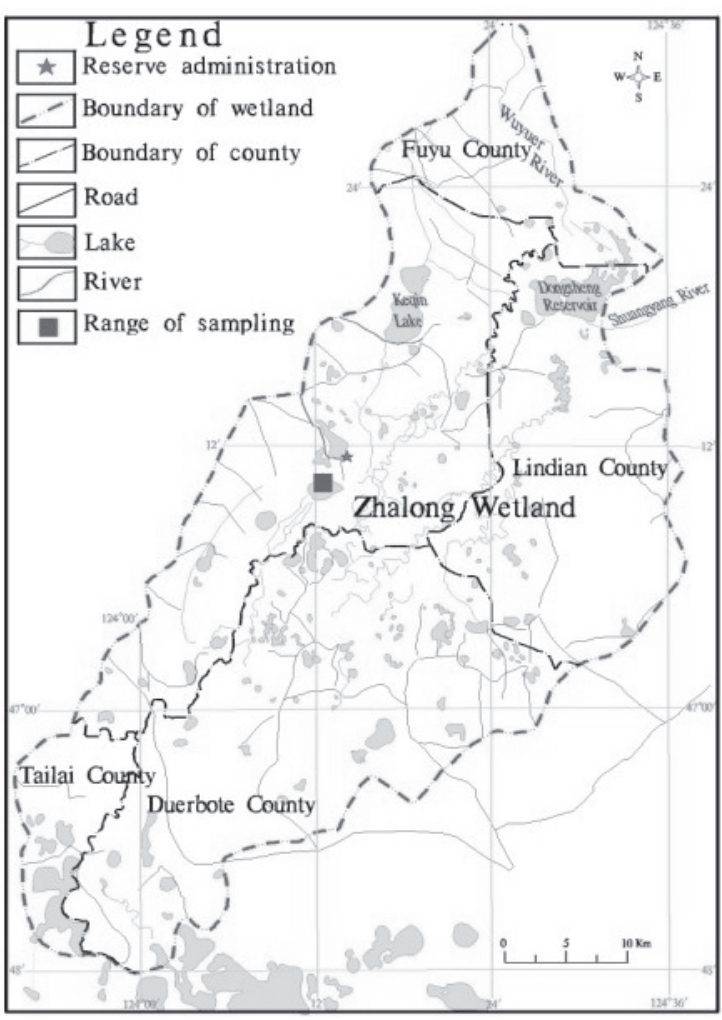

Fig. 1. Zhalong Wetland and range of sampling. were used as the bottom material of pilot-scale wetlands in the experiment. Soil sample was enclosed in the pilotscale wetlands with naturally packed density and original order (the disturbed samples were collected, bagged on site, and filled as its order in the laboratory because of large soil mass and distant range). The reeds were cut into small fragments of about 2-3 cm with each having a dormant bud. Each fragment with a dormant bud was planted per $10 \times 20 \mathrm{~cm}$ area of the pilot-scale wetland, $2 \mathrm{~cm}$ below the surface land. The dormant buds were observed to sprout up under unsaturated conditions, then pouring water every other day to maintain the water level. Three months later, when the reeds were growing to maturity and roots were growing rapidly, the experiment began. Two pilot-scale wetlands, each $200 \mathrm{~cm}$ long and $50 \mathrm{~cm}$ wide, were installed and operated in the experiments for repetition and comparison. A photo of the experimental apparatus is shown in Fig. 2.

\section{Experimental Methods}

The test was designed to be conducted with the inflow water of six different $\mathrm{pH}$ values coded with the letters $\mathrm{A}$, $\mathrm{B}, \mathrm{C}, \mathrm{D}, \mathrm{E}$, and $\mathrm{F}$ (refer to Table 1 for the $\mathrm{pH}$ values and inflow water concentrations). The water $\mathrm{pH}$ was adjusted by $1: 20 \mathrm{HCl}$ or $1 \% \mathrm{NaOH}$ and measured with a $\mathrm{pH}$ meter (HP9807) and precise $\mathrm{pH}$ paper. The sample interval was $4 \mathrm{~d}$ and observing indexes were the concentration of organophosphorus in water samples and adsorbed in clay, total phosphorus, (TP), $\mathrm{PO}_{4}^{3-}$, and $\mathrm{Ca}^{2+}$. Organophosphorus pesticide is the bulk of the product that controls plant diseases and insect pests in agricultural production with characteristics of a broad-spectrum, efficiency, and speed. Among them, omethoate can be dissolved by many solvents, including water, ethanol, and hydrocarbons [13$16]$, and it is a material with high tonnage because the annual requirement for it will exceed $1 \times 10^{5}$ tons [17-18]. So the organophosphorus contamination was prepared by omethoate 40 EC sold at market. Organophosphorus in water samples was extracted with Chloroform and detected by a nitrogen phosphorus detector (NPD). Adsorbed

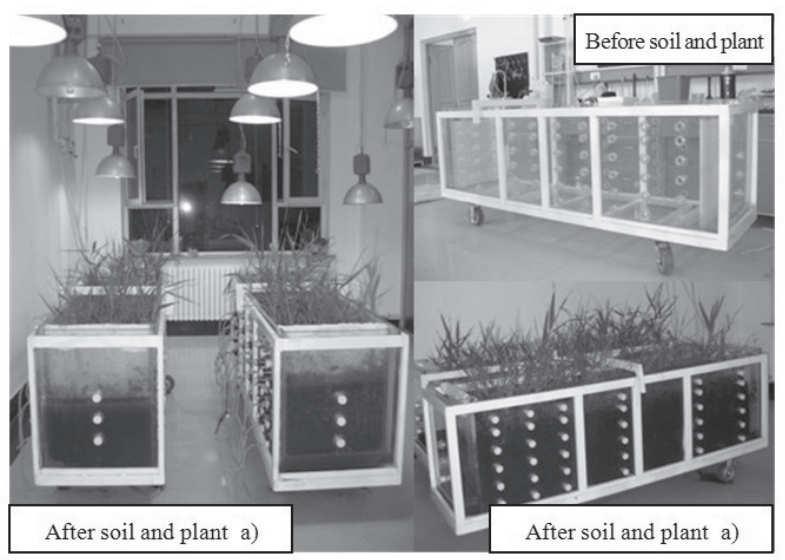

Fig. 2. Installation of lab experiment. 
Table 1. Condition of influent water in the test.

\begin{tabular}{|c|c|c|c|c|c|c|c|}
\hline \multicolumn{2}{|c|}{ Concentration $(\mathrm{mg} / \mathrm{L})$} & & \multicolumn{2}{c|}{$\mathrm{pH}$} & \\
\hline Organophosphorus & $\mathrm{Ca}^{2+}$ & $\mathrm{A}$ & $\mathrm{B}$ & $\mathrm{C}$ & $\mathrm{D}$ & $\mathrm{E}$ & $\mathrm{F}$ \\
\hline 1.69 & 36.52 & 6.5 & 7.0 & 7.5 & 8.0 & 8.5 & 9.0 \\
\hline
\end{tabular}

organophosphorus was extracted by acetone, water, and dichloromethane, and detected by gas chromatography of a nitrogen and phosphorus detector (GC/NPD).

\section{Results and Discussion}

\section{Influence of $\mathrm{pH}$ Value on Migration Performance of Organic Phosphorus}

Table 2 shows the values of organic phosphorus contents in the inflow water after the latter passes by the clay pan. The data of six groups observed in test conditions shows that the content of organic phosphorus in the inflow water decreases while $\mathrm{pH}$ value increases, and the content of organic phosphorus in the inflow water on day 24 is less than $0.2 \mathrm{mg} / \mathrm{L}$ when $\mathrm{pH}=9.0$. We analyzed the organic phosphorus being converted into $\mathrm{PO}_{4}^{3-}$ at higher speeds in the condition of high $\mathrm{pH}$ value, and the phosphate radical is easy to absorb on the surface of the soil particles, which results in a great increase of the $\mathrm{PO}_{4}^{3-}$ absorbed in the clay soil when $\mathrm{pH}=9.0$ (see Table 3 ). It can be seen that $\mathrm{pH}$ value plays a significant role in the migration and conversion of organic phosphorus, that is, the migration performance of organic phosphorus in the clay pan declines while $\mathrm{pH}$ increases.

\section{Influence of $\mathrm{pH}$ Value on Mineralization Rate of Organic Phosphorus}

The mineralization of organic phosphorus refers to its degradation and conversion process and the mineralization rate is used to indicate the extent of degradation and conversion. Organic phosphorus first

Table 2. Data on organophosphor in water sample under different $\mathrm{pH}$.

\begin{tabular}{|c|c|c|c|c|c|c|}
\hline \multirow{2}{*}{ Test } & \multicolumn{6}{|c|}{ Tffluent concentration (mg/L) } \\
\cline { 2 - 7 } & \multicolumn{6}{|c|}{ Time/d } \\
\cline { 2 - 7 } & 4 & 8 & 12 & 16 & 20 & 24 \\
\hline A & 0.82 & 0.62 & 0.75 & 1.04 & 0.52 & 0.40 \\
\hline B & 0.67 & 0.68 & 0.53 & 0.41 & 0.42 & 0.46 \\
\hline C & 0.71 & 0.78 & 0.63 & 0.44 & 0.49 & 0.44 \\
\hline D & 0.87 & 0.59 & 0.55 & 0.41 & 0.32 & 0.56 \\
\hline E & 0.67 & 0.59 & 0.41 & 0.38 & 0.35 & 0.23 \\
\hline F & 0.50 & 0.32 & 0.27 & 0.16 & 0.19 & 0.14 \\
\hline
\end{tabular}

produces $\mathrm{PO}_{4}^{3-}$, which is migrated or converted in the mineralization process. The mineralization degree can be expressed by the ratio of reduced organic phosphorus to the original content (Table 4).

The content of organic phosphorus in the inflow water of Groups B-F in the test conditions on day 16 was about $0.4 \mathrm{mg} / \mathrm{L}$, and the mineralization rate reached $74 \%$ or above while the mineralization rate of inflow water in Group F reached $90 \%$. Only the mineralization rate of inflow water in Group A was $39.44 \%$ on day 16 and exceeded $75 \%$ on day 24.

Part of the $\mathrm{PO}_{4}^{3-}$ produced in the mineralization of organic phosphorus flows out with water and the other is absorbed by the clay pan and left in the clay (Table 3). Fig. 3 shows the variation of $\mathrm{PO}_{4}^{3-}$ in the effluent of the six groups: the content of $\mathrm{PO}_{4}{ }^{3-}$ in Groups A-F declines gradually and the gradient of the content of $\mathrm{PO}_{4}^{3-}$ rises with the increase of the $\mathrm{pH}$ value as a whole.

\section{Chemical Kinetic Characteristics of Migration of Organic Phosphorus}

The test studied the chemical kinetic equitation between $\mathrm{PO}_{4}^{3-}$ and $\mathrm{Ca}^{2+}$ in water and the standard Gibbs free energy change of reaction $\left(\Delta G_{\mathrm{r}}{ }^{0}\right)$ of chemical reaction that may take place between $\mathrm{PO}_{4}^{3-}$ and $\mathrm{Ca}^{2+}$ was calculated, and the $\mathrm{K}$ value was obtained through the relationship between the $\Delta G_{\mathrm{r}}^{0}$ and equilibrium constant, and then the dominant chemical reaction between $\mathrm{PO}_{4}^{3-}$ and $\mathrm{Ca}^{2}$ was determined. The $\Delta G_{\mathrm{f}}^{0}$ of ions and compounds can be found in Environmental Aquatic Chemistry [19].

\section{Kinetic Relationship of c-pH}

The following chemical reactions may take place between $\mathrm{PO}_{4}^{3-}$ and $\mathrm{Ca}^{2+}$ :

Table 3. Related indexes in the test.

\begin{tabular}{|c|c|c|}
\hline Test & $\begin{array}{c}\mathrm{Ca}^{2+} \text { absorbed in the } \\
\text { clay soil }(\mathrm{mg} / \mathrm{g})\end{array}$ & $\begin{array}{c}\mathrm{PO}_{4}^{3-} \text { absorbed in the } \\
\text { clay soil }(\mathrm{mg} / \mathrm{g})\end{array}$ \\
\hline $\mathrm{A}$ & $0.31 \pm 0.03$ & $0.0014 \pm 0.0002$ \\
\hline $\mathrm{B}$ & $0.28 \pm 0.01$ & $0.0032 \pm 0.0007$ \\
\hline C & $0.32 \pm 0.06$ & $0.0025 \pm 0.0003$ \\
\hline $\mathrm{D}$ & $0.36 \pm 0.05$ & $0.0027 \pm 0.0004$ \\
\hline E & $0.40 \pm 0.02$ & $0.0049 \pm 0.0003$ \\
\hline F & $0.27 \pm 0.03$ & $0.0068 \pm 0.0004$ \\
\hline
\end{tabular}




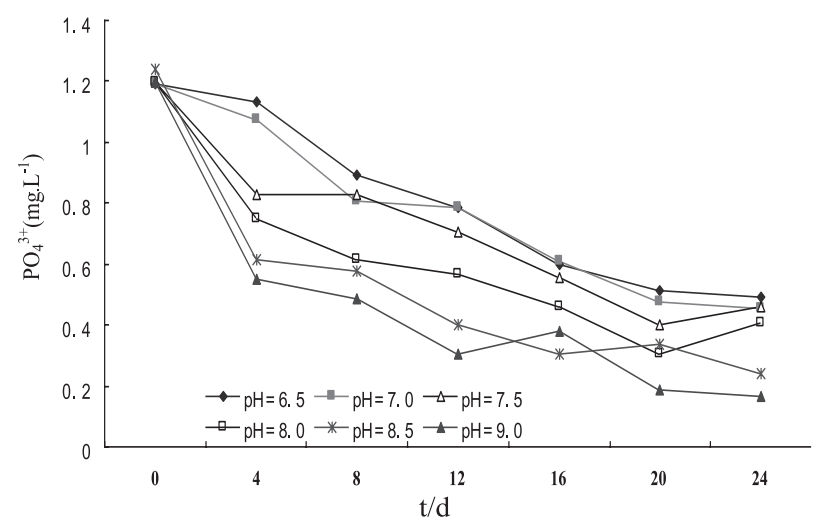

Fig. 3. Relationships between $\mathrm{PO}_{4}{ }^{3-i n f l u e n t}$ concentration and time with different $\mathrm{pH}$.

$$
\left\{\begin{array}{l}
\mathrm{Ca}^{2+}+2 \mathrm{PO}_{4}^{3-}=\mathrm{Ca}\left(\mathrm{PO}_{4}\right)_{2}(\alpha) \\
5 \mathrm{Ca}^{2+}+3 \mathrm{PO}_{4}^{3-}+\mathrm{OH}^{-}=\mathrm{Ca}_{5}\left(\mathrm{PO}_{4}\right)_{3}(\mathrm{OH}) \\
3 \mathrm{Ca}^{2+}+2 \mathrm{PO}_{4}^{3-}=\mathrm{Ca}_{3}\left(\mathrm{PO}_{4}\right)_{2}(\beta) \\
3 \mathrm{Ca}^{2+}+2 \mathrm{PO}_{4}^{3-}=\mathrm{Ca}_{3}\left(\mathrm{PO}_{4}\right)_{2} \\
\Delta G_{r}{ }^{0}=\sum\left(\Delta G_{f}^{0} \text { production }\right)-\sum\left(\Delta G_{f}^{0} \text { reactant }\right)
\end{array}\right.
$$

In Formula (5), $\Delta G_{r}^{0}$ is the standard Gibbs free energy change of reaction and $\Delta G_{f}^{0}$ is the standard Gibbs free energy change of formation.

According to the calculation of $\Delta G_{r}^{0}$ of the above chemical equation, the test determined that equations (1) and (2) are the dominant reaction equations between $\mathrm{PO}_{4}^{3-}$ and $\mathrm{Ca}^{2+} . \Delta G_{\mathrm{r}}^{0}$ of equations (3) and (4) can be neglected because they are too small. In standard conditions, the temperature is $298.15 \mathrm{~K}$.

Calculation with Reaction Equation (1):

$$
\log K=-0.175 \Delta G_{\mathrm{r}}^{0},
$$

By checking the numerical table of $\Delta G_{\mathrm{f}}^{0}, \Delta G_{\mathrm{r}}^{0}=1301.5$ $\mathrm{kJ} / \mathrm{mol}$, we can know that $\log K=227.26$.

Table 4. Mineralization rate of organophosphor in the experiment.

\begin{tabular}{|c|c|c|c|c|c|c|}
\hline \multirow{2}{*}{ Test } & \multicolumn{6}{|c|}{ Time/d } \\
\cline { 2 - 7 } & 4 & 8 & 12 & 16 & 20 & 24 \\
\hline A & 52.047 & 63.743 & 55.962 & 39.441 & 69.396 & 76.608 \\
\hline B & 60.819 & 60.234 & 68.772 & 75.906 & 75.205 & 73.041 \\
\hline C & 58.340 & 54.330 & 62.963 & 74.492 & 71.596 & 73.991 \\
\hline D & 49.123 & 65.497 & 67.836 & 75.906 & 81.053 & 67.193 \\
\hline E & 60.702 & 65.497 & 76.023 & 77.778 & 79.430 & 86.550 \\
\hline F & 70.760 & 81.287 & 84.211 & 90.643 & 88.889 & 91.813 \\
\hline
\end{tabular}

Calculation with Reaction Equation (2):

$$
\Delta G_{\mathrm{r}}^{0}=-356.9 \mathrm{~kJ} / \mathrm{mol}, \log K=62.46 .
$$

Combining (1) and (2):

$$
6 \mathrm{Ca}^{2+}+5 \mathrm{PO}_{4}^{3-}+\mathrm{OH}^{-}=\mathrm{Ca}\left(\mathrm{PO}_{4}\right)_{2}(\alpha)+\mathrm{Ca}_{5}\left(\mathrm{PO}_{4}\right)_{3}(\mathrm{OH})
$$

From $K=\frac{1}{\left[\mathrm{Ca}^{2+}\right]^{6}\left[\mathrm{PO}_{4}^{3-}\right]^{5}\left[\mathrm{OH}^{-}\right]}$we can see that

$$
\begin{gathered}
\log \left[\mathrm{PO}_{4}{ }^{3-}\right]=\frac{14-p H-6 \log \left[\mathrm{Ca}^{2+}\right]-\lg \mathrm{K}}{5}, \\
{\left[P \mathrm{O}_{4}{ }^{3-}\right]=10^{-\frac{p H}{5}} \cdot D_{1},} \\
D_{1}=10^{\frac{14-6 \log \left[\mathrm{Ca}^{2+}\right]-\log K}{5}},
\end{gathered}
$$

$\log \left[\mathrm{Ca}^{2+}\right]$ and $\log \mathrm{K}$ are both state,

$$
\log c=-\frac{p H}{5}+M, M=\lg D_{1}
$$

Refer to Fig. 4 for the data observed in the variation of $\log c$ with the $\mathrm{pH}$ value of the inflow water. When $\mathrm{pH}$ value is between 6.5 and $9.0\left(\mathrm{PO}_{4}^{3-}\right.$ content of inflow water is $0.39 \mathrm{mg} / \mathrm{L}$ ), the logc declines with the increase of $\mathrm{pH}$ value with the gradient -0.1729 .

\section{Kinetic relationship of $c-t$}

The test analyzed the first-order equation between $\mathrm{c}$ and $t$ of types of ion:

From $\frac{d c}{d t}=k_{1} c$,

We get $\frac{d c}{c}=k_{1} d t$,

$c=e^{k_{1} t+A_{1}}$

So $c=A_{2} e^{k_{1} t}\left(A_{2}=e^{A_{1}}\right)$

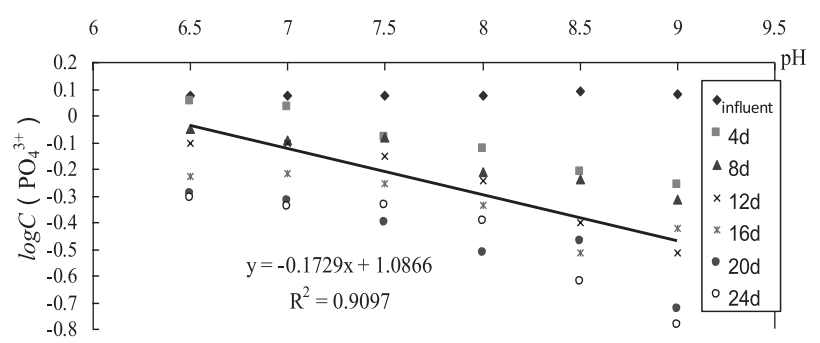

Fig. 4. Relationships between $\mathrm{pH}$ and $\log c$ of $\mathrm{PO}_{4}^{3-}$. 


$$
\ln c=k_{1} t+N, N=\ln A_{2}
$$

Refer to Fig. 5 for the data observed in the variation of $\ln c$ with the time. It can be seen that the $\ln c$ of the six groups of $\mathrm{pH}$ value declines with time passing, and the gradient is between -0.0417 and -0.0746 . Therefore, the lnc declines continuously with the time passing in the condition of six groups of $\mathrm{pH}$ values, and its gradient is between -0.0417 and -0.0746 .

\section{Conclusions}

1) For this paper we simulated wastewater containing organic phosphorus degradation process across the wetland via organic phosphorus containing solutions of different $\mathrm{pH}$ values slowly passing the simulation groove so as to explore the chemical
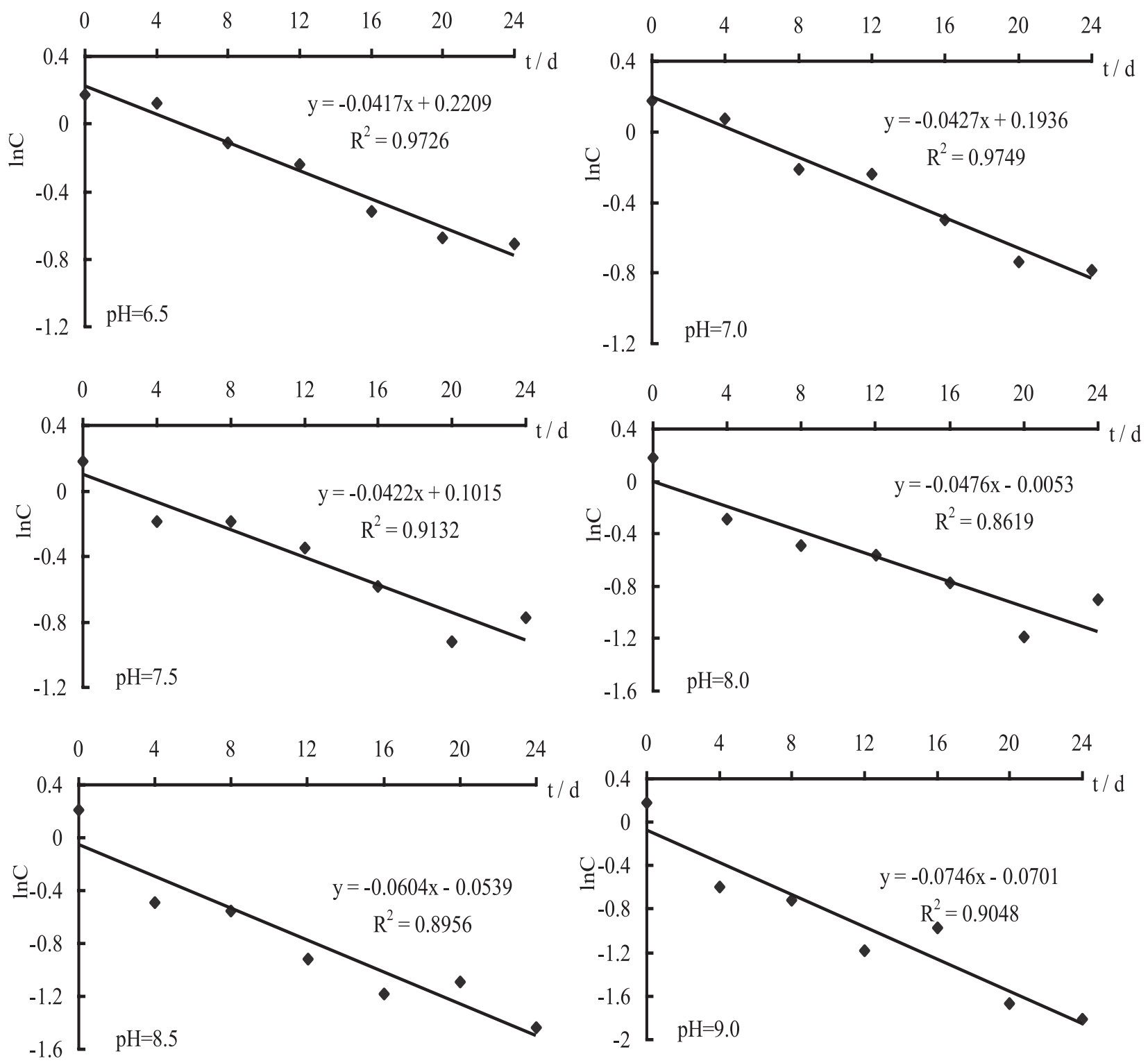

Fig. 5. Relationships between time and $\ln c$ of $\mathrm{PO}_{4}{ }^{3-}$. 
the purification mechanism and determine chemical kinetic mode of organic phosphorus migration in the aqueous background of wetlands.

\section{Acknowledgements}

This research is supported by the Youth Foundation of Jilin Provincial Department of Science and Technology (Grant No. 20160520087JH) and the Seed Foundation of Changchun Institute of Technology (Grant No. 320160024, 320150026). The authors express their gratitude for help from the Jilin Provincial Key Laboratory of Municipal Wastewater Treatment, the Laboratory of Applied Disaster Prevention in Water Conservation Engineering of Jilin Province, and the Key Laboratory of Wetland Ecology and Environment at the Northeast Institute Of Geography and Agroecology, and the Chinese Academy of Science staff for help with laboratory sampling and analyses. We thank the students for help with fieldwork and Sun Guangzhi for his very helpful review.

\section{References}

1. LI W.D., LIU Y.G., TIAN K., LIANG Q.B., LIU H.F. Research on purification effect of Jian Lake Zizania latifolia wetland lakefront zone in northwest of Yunnan Plateau on nitrogen and phosphorus of agricultural non-point source[J]. Agricultural Science\& Technology, 11 (7), 109, 150, 2010.

2. XU H.S., ZHAO T.Q., HE Y.X., XU Z.X., MA C.H. Effect of different vegetation types on agricultural non-point nitrogen pollution in riparian wetlands. Acta Ecologica Sinica, 30 (21), 5759, 2010.

3. YAO X., YANG G.S. Progress on the Study of Water Purification Ability of Natural Wetlands. Progress In Geography, 28 (5), 825, 2009.

4. ZZHU W.F., LIU Y.J., MA Y.S. Research on the purity effect of agricultural non-point pollution that natural wetlands to Hamatong river basin in Sanjiang Plain. Journal of Northesat Agricultural University. 40 (5), 58, 2009.

5. JAN V. Removal of nutrients in various types of constructed wetlands.Science of the Total Environment. 380 (1-3), 48, 2007.

6. WEN B.L., LIU X.T., WANG J.F. Current State of Water Environment Quality and Pollution Rrevention
Countermeasures of Wetlands in Daqing Oil Developent Zones. Wetland Science, 8 (4), 312, 2010.

7. SUN T.T., LIN W.P., CHEN G.S., GUO P.P., ZENG Y. Wetland ecosystem health assessment through integrating remote sensing and inventory data with an assessment model for the Hangzhou Bay, China. Science of The Total Environment, 566-567, 627-640, 2016.

8. SUN Z.G., MOU X.J., CHEN X.B., WANG L.L., SONG H.L., JIANG H.H. Actualities, Problems and Suggestions of Wetland Protection and Restoration in the Yellow River Delta. Wetland Science, 9 (2), 107, 2011.

9. YE Y.J., LUO J.M., WANG Y.J., YIN X.R., WANG W.F. Trophic state of Zhalong Wetland and the comprehensive assessment. Journal of Arid Land Resources and Environment, 26 (11), 110, 2012.

10. LI H.Y. Study on Water Quality Purification Mechanism and Purification Function of Zhalong Wetland. Changchun, Northeast Institute of Geography and Agroecology, Chinese Academy of Sciences, 2011.

11. SUN Q.Z, ZANG S.Y., ZHANG N.N., NA X.D. Evaluation of Water Environment Quality of Zhalong Wetlands based on Monte Carlo Method. Wetland Science, 11 (1), 75,2013.

12. H.Y., ZHANG G.X., LI X.Q., GAO R. Spatial Characteristics of Water Quality of Wetland in Northeast China-the Case of Zhalong Wetland. Procedia Environmental Sciences, 12 (Part B), 1024, 2012.

13. HEE J.K., CHUL J.L., MOHAMMAD R.K., MAK S.K., MU S.L. Surface- enhanced Raman spectroscopy of Omethoate adsorbed on silver surface. Molecular and Biomolecular Spectroscopy, 78 (1), 179, 2011.

14. TAO Y.G., WANG Y.M., YAN S.L., YE L.B. Optimization of omethoate degradation conditions and a kinetics model. International Biodeterioration \& Biodegradation, 62 (3), 239, 2008.

15. WANG L., ZHANG L.J., LV W., HAN S.H., ZHANG F.K., PAN J.R. Determination of Organophosphorus Pesticides Based on Biotin-Avidin Enzyme-Linked Immunosorbent Assay. 39 (3), 346, 2011.

16. ZHAN D.S., WANG J.L., ZHAO X.H., ZHANG J. $\mathrm{TiO}_{2} / \mathrm{NaY}$ Composite as Photocatalyst for Degradation of Omethoate. Chem. Res. Chinese Universities, 25 (4), 543, 2009.

17. LI R.X., YANG C.P. Progress of Treatment Technologies for Organic Phosphorous Pesticide Wastewater. Environmental Science and Management, 33 (9), 84, 2008.

18. HE W.X., ZHENG F.L., TIAN H.X. Effect of Omethoate on Soil Enzyme Activities. Scientia Agricultura Sinica, 42 (12), 4282, 2009.

19. LI X.Q. Aqueous Environmental Chemistry. Changchun: Jilin Science and Technology Press: 265, 2001. 